\title{
The relationship between changes in money supply and changes in share prices: the semi-strong form efficiency of the Johannesburg Stock Exchange revisited
}

\author{
R.D. Glass \& E. vd M. Smit* \\ Graduate School of Business, University of Stellenbosch, P.O. Box 610, Bellville 7535, Republic of South Africa
}

Received November 1994

\begin{abstract}
In this article the semi-strong form of share market efficiency over the period 1978 to 1992 is considered, particularly with regard to information about changes in the money supply. To ensure a rigorous test of market efficiency, monetary growth has been decomposed into anticipated and unanticipated elements. The All Share Index of the Johannesburg Stock Exchange is regressed against the monetary variables. The test results indicate that lagged changes in anticipated monetary growth are significant in explaining changes in share prices, a finding contrary to the efficient market hypothesis. However, the low coefficients of determination indicate that only a small percentage of the variation in share prices is explained by ex post changes in money supply and consequently the potential for a trading rule to earn superior returns to the market is limited.
\end{abstract}

In hierdie artikel word die semi-sterk vorm van aandelemarkdoeltreffendheid gedurende die periode vanaf 1978 tot 1992 beskou, hoofsaaklik met betrekking tot die inligting rakende veranderings in die geldvoorraad. Om 'n streng toets vir markdoeltreffendheid te verseker, word geldvoorraadgroei onderverdeel in verwagte en onverwagte elemente. Regressies van die Algehele Indeks van die Johannesburgse Effektebeurs is toegepas op die geldvoorraadveranderlikes. Die resultate dui daarop dat die gesloerde veranderings in die verwagte geldvoorraadgroei betekenisvolle voorspellers van veranderings in aandeelpryse is, ' $n$ bevinding wat teenstrydig is met die doeltreffende markhipotese. Die lae bepaaldheidskoëffisiënte is egter ' $n$ aanduiding dat slegs ' $n$ klein persentasie van die variasie in aandeelpryse deur ex post veranderings in die geldvoorraad verklaar word en derhalwe is die potensiaal vir 'n handelsreël wat hoër opbrengste as die mark lewer. beperk.

*Author to whom correspondence should be addressed.

\section{Introduction}

The efficiency of capital markets in the allocation of financial resources has long been the subject of a contentious debate both within academic and non-academic circles. Proponents of efficient markets contend that current share prices reflect all available information and are therefore an unbiased estimate of the intrinsic value of the underlying asset. Furthermore, the intrinsic value of a share adjusts instantaneously to new information that may have a bearing on the value of the underlying asset. The implication of share prices being unbiased estimates of their intrinsic value is that it prevents the development of a trading rule which delivers a superior return above that which is readily available in the market.

A market is efficient with respect to an information set $\theta_{t}$ if it is impossible to profit from trading on the basis of that information set (Jensen, 1978: 96). In this article the extent to which the JSE meets the requirements for semi-strong form efficiency is explored, specifically with regard to information concerning changes in the money supply. It flows from and extends the methods and results of Bhana (1993) in three directions. First, the theoretical link between money supply and share prices is considered more carefully, and instead of using a single mechanism to separate anticipated and unanticipated money growth, four different specifications are utilized, thus generalizing the process giving rise to anticipation formation. Second, it has been shown that share return-inflation relationships are sensitive to the choice of monetary regime (Smit \& Philip, 1992). The period covered by Bhana (1993) spans overlapping regimes. Therefore, in the current study the total sample period is also restricted to correspond with the period over which Smit \& Philip (1992) have established evidence of market efficiency in share return-inflation relationships. In the third place, the current study utilizes monthly instead of quarterly data as used by Bhana (1993). Money supply information reaches the market on a monthly basis and thus the current approach is more in line with what has become the standard approach in event studies. Furthermore, Fama (1990) has demonstrated that longer return horizons (quarterly versus monthly) tend to explain more return variation, thus causing a bias against the acceptance of market efficiency in studies of this nature where efficiency is indicated by the absence of significant regression and low coefficients of determination.

The article is structured in the following way; in the second section the theoretical link between money supply and share prices is discussed, followed in the third section by a literature study on market efficiency with respect to monetary policy information. The fourth section offers the theoretical basis for the distinction between anticipated and unanticipated changes in money supply. The research method and results are respectively outlined in the fifth and sixth sections, followed by the conclusion.

\section{Theoretical link between money supply and share prices}

The classical monetarist approach suggests that changes in the money supply have a direct and predictable impact on the economy, including the prices of assets. According to the Fisher equation a change in the money supply, assuming constant velocity, will result in a change in either the level of prices or the level of output in an economy. Both these consequences have an impact on share prices either directly, as is the case if the levels of prices in an economy change, or indirectly through increased output and consequently an increase in the intrinsic value of shares.

Hafer (1986) highlights three reasons why share prices will react to unanticipated changes in the money supply. The 
expected inflation hypothesis arises from the Fisher effect and the expectation that an increase in the money supply will result in a rise in interest rates and higher inflation. Based on the present value model of share prices, the higher interest rates will reduce the present value of shares, thus causing the prices of shares to decline. The ability of this model to hold in the short term needs to be questioned as only a sustained increase in monetary growth would result in an expected increase in inflation. Furthermore, the extent to which the expected increase in inflation and interest rates impacts on the price of a share is not clearly determinable as the rise in the price level may also be reflected in a rise in the income of the underlying companies. Consequently the impact on share prices based on a discounted cash flow model may be neutral depending on the underlying assumptions such as the impact of fiscal drag and long term inflationary expectations.

A second reason is found in the risk premium effect and policy anticipations hypothesis. Hamburger \& Kochin (1972) describe the risk premium effect as being the impact on share prices of a change in the variability of money supply. Volatility caused by movements in the supply of money are likely to raise the risk premium demanded by shareholders. Consequently the price of shares will fall as the discount rate of the future income stream increases. According to the policy anticipations hypothesis any excess growth in the money supply will result in stricter anticipated monetary policy and a consequent rise in interest rates. Based on the discounted cash flow approach to share prices, this will result in a reduction in the share price level as the present value of the income stream is reduced. A particular concern of this theory is that, given rational expectations, the market will anticipate that interest rates will fall following a reduction in the monetary growth rate. thus causing the prices of shares to rise. Depending on the time horizon of the investor, the policy anticipations hypothesis may not hold as the net effect of the change in the monetary growth rate and reactionary monetary policy is a return to the long term dynamic equilibrium interest rate. Consequently, assuming no indirect impact on the income stream of a particular share, the present value of the income may largely be unaffected.

The third reason for a link between changes in share prices and money supply proposed by Hafer (1986) is the real activity hypothesis; or earnings effect as discussed by Hamburger \& Kochin (1972). The real activity hypothesis postulates that an unexpected increase in the money supply signals an increase in output. Consequently share prices will rise as the income stream of the underlying company for which the share is being traded will rise due to the higher level of activity. This hypothesis makes a clear distinction between anticipated and unanticipated changes in real activity and is therefore not in conflict with rational expectations theory. However, a problem arises when attempting to distinguish whether the change in money supply is as a result of an increase in real activity or inflationary pressure. Unless the operational environment of the economy has changed, the market expectation is unlikely to conclude that the change in monetary growth is related 10 an increase in real activity.

A fourth hypothesis on the link between changes in money supply and changes in share prices. the monetary portfolio hypothesis. is discussed by Bhana (1993). According to this hypothesis, an unexpected change in the monetary growth rate results in a change in the equilibrium position of money with respect to other assets in investors' portfolios. Assuming an unexpected increase in money supply, investors will have excessive monetary holdings in their portfolios. Individual investors will attempt to rectify the state of disequilibrium, however, the system as a whole cannot adjust. Consequently the relative value of non-monetary assets will have to rise as adjustment takes place through the price mechanism. This hypothesis is similar to the liquidity effect discussed by Hamburger \& Kochin (1972) which posits that an increase in the stock of money decreases the value of a portfolio and therefore decreases the demand for money. Adjustment is achieved through a decline in interest rates.

It is evident from the foregoing discussion that the theoretical basis for a relationship between change in monetary growth and share prices is not uniquely defined. A contradiction exists between the long and short term adjustments which are dependent on the underlying reasons for the change in the money supply, namely, as a result of an increase in real activity or an over-heating of the economy. This article is, however, not concerned with the validity of the hypotheses set out above. Rather, it focuses on the empirical relationship between changes in share prices and monetary growth. There clearly exists theoretical bases linking changes in money supply and share prices.

\section{Empirical evidence on market efficiency with ro- spect to monetary policy information}

The different viewpoints noticable in the theoretical underpinings have been carried forward into empirical research in the area. Early work in this regard was undertaken by Sprinkel (1964) who concludes that changes in money supply has a lagged impact on share prices. Hafer (1986) finds that unanticipated changes in money supply do have a statistically significant and negative effect on share prices thus supporting the expected inflation and policy anticipations hypotheses. Furthermore, he finds that expected changes in money supply do not significantly affect share prices. Hafer's (1986) work thus supports the findings of Pearce \& Roley (1983), who conclude that market efficiency cannot be rejected at conventional significance levels. It should be noted that these findings, and the supported hypotheses, contradict Sprinkel's (1964) monetary portfolio model.

Rozeff (1975) takes the efficient market view whereby profit seeking investors will exploit available information quickly, ensuring no systematic delayed reaction. In testing Sprinkel's (1964) model, Rozeff (1975) draws the conclusion that a mere $1 \%$ of the variation in share prices is explained by ex post changes in the money supply. Furthermore, evidence is produced indicating that contemporaneous changes in the money supply are strongly linked to changes in share prices and that share returns anticipate changes in the money supply. Further analysis by Rozeff (1975) of Sprinkel's (1964) trading rule indicates that the rulc is an after-the-fact selection of particular peaks and troughs in a specific period. The test for market efficiency should be based on an unambiguous statistical method to test for the relationship between money supply and share prices. Applying such a procedure, Rozeff 
(1975) concludes that published money supply figures seem worthless as indicators of the future direction of share prices.

As an aside, Hamburger \& Kochin (1972) evaluate the direct impact of changes in the money supply on share prices as opposed to the widely accepted indirect impact through interest rate movements. A semi-reduced form equation is defined replacing the interest rate variable with its determinants namely, the rate of growth of real income, the change in money supply and the expected inflation rate. The conclusion of their research is that the determinants of the interest rate variable are more closely related to equity prices than the interest variable itself. Hence changes in the money supply appear to have a direct impact on share prices.

The hypothesis that changes in the money supply affect share prices with a lag has been both supported and rejected by numerous authors. According to Barro (1977), empirical evidence of the US market for the period 1941-1976 supports the hypothesis that only the unanticipated part of money expansion influences unemployment. In tests undertaken by Bonomo \& Tanner (1983) using three different monetary growth definitions, the hypothesis that such changes have systematic effects on relative prices is rejected.

Homa \& Jaffee (1971) utilize a standard discount model for determining share prices and conclude that the price of a share will be determined by three variables: the level and growth rate of dividends, the riskless rate of interest, and the risk premium. They then show that the money supply is positively related to the level and growth of dividends, and negatively related to the riskless rate of interest and risk premium. With regard to the test for market efficiency, results obtained by Homa \& Jaffee (1971) are not conclusive. Perfect foresight of monetary growth resulted in a significant gain over a buy and hold strategy while results using a naive growth rate forecast were distinctly inferior to the buy and hold strategy.

The hypothesis that forms the basis of Sorensen \& Arnott's (1988) paper is that unanticipated changes in money supply have a more dramatic effect on share prices than do anticipated changes in monetary aggregates. Evaluating such a hypothesis is not without potential flaws to the extent that the magnitude of anticipated changes in money supply usually exceeds that of unanticipated changes. The fact that the market reacts over time and prior to anticipated changes in money supply should not reduce the importance of its impact but rather influence only the impact's timing. Their results are consistent with market efficiency as only the contemporaneous change in unanticipated monetary growth was found to be significant.

Bhana (1993) contends that it is generally agreed that unexpected or unanticipated changes in the growth rate of the money supply result in a change in the equilibrium position of money with respect to other assets in an investor's portfolio. Consequently the relative prices of the assets change as investors attempt to adjust their portfolios to achieve equilibrium. Although individuals may adjust, the system cannot, since all money balances must be held. Equilibrium is therefore reestablished through changes in the price levels of the various assets. Bhana (1993: 32-33) hypothesizes that "it can be expected that the time response of investors may be delayed, ... then changes in the share prices should respond to monetary disturbances with a lag'. Based on the above hypothesis,
Bhana (1993) draws the conclusion that if one can forecast changes in the money supply, one can determine - at least in part - future prices and returns of shares. Such a conclusion contradicts the requirements for market efficiency. Bhana correctly states that this conclusion is only valid if there is a delay in price movements following a change in the money supply. In order to test for market efficiency Bhana (1993) decomposes money growth into anticipated and unanticipated elements to examine the possible existence of lags for both elements. Following the isolation of anticipated and unanticipated changes in monetary growth, he estimates a share price growth equation which includes the rate of inflation and anticipated and unanticipated changes in money supply growth as explanatory variables. Contrary to both rational expectations and market efficiency, Bhana (1993) establishes that changes in share prices are significantly related to lagged values of both anticipated and unanticipated money growth.

It should be noted that empirical research into market efficiency is not without potential pitfalls. Mishkin (1982) questions the validity of the test statistics resulting from the twostep procedure, adopted in much of the research including this article, whereby the money growth equation is estimated over the sample period and the residuals from the regression are then used as the unanticipated changes in monetary growth. Similarly, Rozeff (1974) critically examines the procedures used to test for the performance of a trading rule versus a buy and hold strategy. Issues raised by Rozeff (1974) include: defective treatment of dividends; neglect of transaction costs; various forms of ex post selection bias; failure to adjust for risk; and in-sample versus out-of-sample testing. A further criticism raised by Rozeff (1974) concerns the Almon Lag technique. This technique has been used by Keran (1971) and Hamburger \& Kochin (1972) and constrains the regression coefficients to a polynomial equation. This is a similar procedure to that used by Bhana (1993) and raises a concern about the results as, in Rozeff's view, such a restriction makes it almost impossible for the data to indicate an absence of lags.

\section{Theoretical basis for the distinction between antici- pated and unanticipated changes in the money sup- ply}

Four different methods are used for identifying the anticipated money demand function. Whittaker \& Theunissen (1987) lend credence to the IS-LM money demand equation with income and interest rates as the explanatory variables. This work is taken one step further by Tavlas (1989) who specifies a buffer stock model in order to allow for shock changes in the economy. Barr \& Kantor (1990) base the money demand equation on the application of an autoregressive model with the explanatory variables being GDP, the PCE deflator, the ratio of trade balances to nominal GDP and the lagged value of the dependent variable. The fourth alternative as used by Bhana (1993) is to derive the anticipated monetary growth equation using an atheoretical technique.

In their study on the relevance of the endogeneity of money supply, Whittaker \& Theunissen (1987) conclude that contrary to current orthodoxy, which suggests that money stock is exogenously determined, the Central Bank must set interest rates through which it influences other macro-economic 
variables including the money stock. This implies that the money stock is endogenously determined by the reaction of the economy to prevailing interest rates and other influences. Exogeneity of money supply is an underlying principle of ISLM analysis where the explanatory variables of money are interest rates and income. This model forms the basis for work done by Tavlas (1989) on the money demand function under the policy of monetary targeting. Tavlas (1989) noted that statistical relationships between money and nominal income appeared to break down with the change in the financial environment as deregulation and innovations led to a blurring of the distinctions among monetary aggregates. Tavlas (1989) defines the buffer stock model for money demand which is able to distinguish between shifts in money demand due to traditional factors (such as income and interest rates), and shifts due to unexpected changes in monetary policy.

The buffer stock approach presupposes the need for an asset to absorb shocks during the interval which elapses between the occurrence of a shock and the subsequent response of economic agents. This interval is required due to the cost of gathering and processing information and results in an increase in the demand for real balances during this period. It should be noted that this is not in contravention of the efficient market hypothesis regarding the price of assets. Economic agents may take time to adjust their portfolios in response to the shock, however, prices in efficient markets are hypothesized to adjust immediately.

Following a similar approach, Stadler (1981) derives a money demand equation for the period 1965-1979. The income variable reflects the transaction demand for money while the interest rate variable reflects the demand for idle balances. Stadler (1981) furthers his analysis hy incorporating a partial adjustment coefficient to take account of the discrepancy between actual and desired money balances. This is similar to the approach adopted by Contogiannis \& Shani (1982).

Further insight into the derivation of the anticipated money demand equation is given by Barr \& Kantor (1990). In their work on the application of a vector autoregressive model they contend that money supply growth is both exogenously and endogenously determined. They criticize conventional econometric models of macro-economic systems as the coefficients would reveal simultaneous equation bias. Commencing with the St Louis equation with a monetary aggregate and a measure of high employment federal government expenditure, as explanatory variables, they point out that this is a reduced form equation and therefore important other exogenous variables may be omitted. In contrast to a restrictive approach based on reduced form equations. Barr \& Kantor (1990) derive a vector autoregressive model which expresses each of a set of endogenous variables as a function of lagged values of itself and lagged values of all the other endogenous variables in the system.

Bhana (1993) distinguishes between anticipated and unanticipated changes in the money supply by following an atheoretical statistical procedure. This procedure was proposed by Mishkin (1982) on the basis that it is difficult on theoretical grounds to exclude any piece of information when specifying the money demand equation. Therefore, provided a variable is statistically significant, it is included in the equation. The major criticisms of this approach are that, firstly, it may lead
10 spurious relationships as variables are chosen for their ability to explain past changes in monetary growth and not for their integrity with respect to economic theory. Secondly, it is open to selection bias by the researcher.

\section{Research method}

The objective of this article is to examine the relationship between changes in share prices and changes in the rate of growth of money supply, particularly as regards the lag structure that may exist. Essentially this is a test that the JSE is semi-strong form efficient which for this particular study posits that the share price in time period $t$ reflects all available information concerning changes in the money supply and therefore is the best unbiased predictor of the price in period $t+l$ in regard to monetary policy information. According to the Efficient Market Hypothesis (EMH), share prices change only in response to new information as all available information is reflected in the current price. The requirement for market efficiency is extended further than a simple analysis of the relationship between changes in the monetary aggregate and share prices. Consideration is given to the relationship between anticipated and unanticipated changes in money supply and share prices. Rational expectations theory would suggest that anticipated changes in the money supply are reflected in share prices prior to the realization of the monetary change. For the market to be efficient therefore, contemporaneous and lagged values of anticipated monetary growth should not be significant explanatory variables of share price movements. Similarly, for the EMH to hold, unanticipated contemporaneous changes in the monetary growth rate may be significant in explaining changes in share prices, however, lagged changes in unanticipated monetary growth should not be significant in explaining share price movements.

In order for meaningful conclusions to be made from this research, it is therefore necessary that the money supply change be decomposed into anticipated and unanticipated change. The method followed therefore was firstly to decompose monetary growth by specifying a monetary growth equation. Anticipated monetary growth is represented by the predicted values of the equation while the residuals from these equations are considered to be the unanticipated component of monetary growth. The following null hypotheses are tested:

$\mathrm{H}^{1}$ Contemporaneous and lagged changes in anticipated monetary growth are not significant in explaining changes in share prices.

$\mathrm{HO}^{2}$ Lagged changes in unanticipated monetary growth are not significant in explaining changes in share prices.

The two hypotheses relate specifically to the test of market efficiency. The rejection of either one of the two null hypotheses would result in the rejection of the Efficient Market Hypothesis. The inclusion of contemporaneous changes in the first hypothesis is based on the method used to derive anticipated monetary growth. The anticipated monetary growth model is derived from historical economic information with a minimum time lag of one period.

If the contemporaneous change in anticipated monetary growth is found to be a significant explanatory variable of changes in share prices, this would lead us to reject the 
hypothesis that the market is efficient as the contemporaneous anticipated monetary change reflects information that is available when the change in the share price is recorded. The efficiency hypothesis further implies that lagged coefficients on the unanticipated moncy growth should also be zero because these coefficients relate historical values of unanticipated money growth to changes in current share prices. Only the contemporaneous coefficients on the unanticipated money growth represent the value of new information regarding changes in monetary policy.

The majority of macro-economic data in South Africa has as its primary source either the South African Reserve Bank (SARB) or the Central Statistical Service (CSS). The secondary source through which the majority of the data was obtained is the Ivor Jones Inc. database system. A further source for the data is the Standard Bank database system.

In any investigation including money supply as an explanatory variable, a decision is required as to which monetary aggregate should be used. Monetary aggregates range from the narrowly defined MlA, which includes physical money in circulation and cheque and transmission deposits, to the more broadly defined M3 which includes amongst others, all short. medium and long term deposits. By definition, M1A is more liquid and therefore less prone to measuring errors. Broadly defined monetary aggregates are subject to measurement distortions due to such factors as disintermediation and foreign exchange movements although they are less vulnerable to financial innovations which cause a relative change between the monetary aggregates. The advantage of M3 over M1A is that it captures all available information regarding the money supply. In order to overcome this issue of choice, experiments have been conducted with both variables.

A further consideration in this analysis regards the availability of historic data on monetary aggregates. Logically consistent times series published by the SARB go back as far as 1978 and therefore the time period for this research has been restricted to the period from 1978-1993, giving some 150 data points depending on the lead and lag structure.

This research is based on monthly data thus imposing a de facto limitation on the number of time series available, as quarterly time series are excluded. The extent of this limitation is however not considered onerous. Monetary growth rates and share price indices are published on a monthly basis as are numerous indicators of real growth.

Utilizing the data supplied by the primary sources, the SARB and CSS, raises two important issues. Firstly, publications lags are implicitly assumed to equal one month. The second major issue concerning the data source is with regard to data correction errors. The anticipated monetary growth models specified in this article are based on the corrected time series of the dependent and independent variables. Economic agents base their expectation of the next value of a series on the lagged data available at that time, before corrections. The impact of data corrections has not been quantified and is implicitly assumed to be insignificant. A further limitation of this analysis, particularly as regards the derivation of anticipated and unanticipated monetary growth, is that the regression model is specified based on the data over the full period. Once the model has been specified, anticipated monetary growth is derived by applying the data of the explanatory variables to the regression equation over the full period. The unanticipated monetary growth is then taken to be the residual between actual and anticipated monetary growth. Economic agents acting at time $t$ will base their forecasts on information published before time $t$ and will not have the benefit of specifying a model that fits the data best over the full period. The underlying assumption of this approach is that the parameters are stationary over time and thus the intercept and coefficients of the model will not differ significantly between periods.

A further consideration required when specifying a model based on monetary aggregates is the extent to which policy regimes change and therefore directly affect the causal relationships between the dependent and explanatory variables. The distinction between different policy regimes is based on the macro-economic targets of the monetary authorities. Variables targeted include interest rates, exchange rates, money supply growth and economic growth. Smit \& Philip (1992) identified three periods in recent South African history when differing policy regimes applied. The interest rate regime was a period of direct control as associated with Keynesian economics from the early 1960 s to 1978 . During this period monetary policy played a passive role in the economy as attention was focused on fiscal policy to achieve macro-economic objectives. The interest rate regime was followed by the free market period from 1979 to 1983. This is considered by Smit \& Philip (1992) to be the transition period from direct controls to a more market-related era. The transition period was followed by the money supply regime from 1984 to 1991 during which monetary policy was largely based on targeting money supply growth. For the purpose of this research, only the latter regime was taken into consideration by imposing a restriction on the time period when deriving the anticipated monetary growth equations. All models were specified for both the restricted period (1984-1991) and the full period.

All the explanatory time series were tested for seasonality using the Forecast Master Plus programme. Where seasonality was indicated, indices were derived and the data deseasonalized. Evidence of seasonality was found in the two series that measure real economic activity, namely, the rate of change in retail sales and rate of change in the manufacturing production index.

In order to determine the anticipated change in monetary growth for the South African economy, four models were specified with the rate of change in the money supply as the endogenous variable. The theoretical basis for these models is discussed in the fourth section. The initial models were as follows:

1. A model based on the classical IS-LM analysis of money demand. The exogenous variables are as follows: (a) seasonally adjusted rate of change in the Manufacturing Production Index (MPI) - as a proxy for income; (b) the rate of change in the BA rate; and (c) the lagged dependent variable.

2. A model based on research undertaken by Barr \& Kantor (1990) with the following exogenous variables: (a) the MPI as indicated in (la) above; (b) the growth rate in the Consumer Price Index; (c) the rate of change of gold and foreign exchange reserves; and (d) the lagged dependent variable. 
3. An atheoretical model taking into consideration a wide range of macro-economic variables. The final model included the following independent variables: (a) seasonally adjusted rate of change in retail sales; (b) the rate of change in the BA rate; $(c)$ the growth rate in the Consumer Price Index; (d) the rate of change of gold and foreign exchange reserves; and (e) the lagged dependent variable.

4. A model, identified by Bhana (1993), based on research on the South African economy. The independent variables are as follows: (a) the rate of change in the BA rate; (b) the rate of change of gold and foreign exchange reserves; and (c) the lagged dependent variable.

It should be noted that none of the models were strictly adhered to; rather they formed the basis for the derivation of the anticipated monetary equation. The initial models were constructed with the growth rate in MIA (DMIA) as the dependent variable. Monthly data was used for the period 1978-1993. The appropriate own lag length of the dependent variable was determined, following which all the independent variables were individually regressed against DM1A to determine their individual lag structure.

The lag length was limited to a maximum of 24 months. The models were then tested to ensure no significant lagged variables had been omitted. An iterative procedure was followed until the lag structure was obtained with all the variables significant at the $5 \%$ level. The basis for inclusion of a particular variable was the Student-t statistic while consideration was also given to the Durbin-Watson statistic and coefficient of determination.

The individual models were then specified with the lag structure of all the explanatory variables as previously identified. An iterative procedure was again followed to find the best model based on the Student-l statistic, coefficient of determination and Bayes Information Criterion (BIC). The Bayes Information Criterion statistic is aimed at improving the out-of-sample forecast accuracy and is therefore applicable to this research as the monetary growth models are directed at identifying the markets' forecast of changes in money supply. No variables were rejected if, on the basis of the Student-1 statistic, they met the $5 \%$ significance requirement.

All the models were examined for serial correlation and heteroscedasticity. The Durbin-Watson statistic was used to identify the presence of first-order serial correlation. This statistic is supported by the Ljung-Box test which tests for autocorrelation up to the maximum lag length. No adjustments were made in models where signs of heteroscedasticity were present. The models were also specified for the period from 1984 to 1991. No attempt was made to further isolate the effect of monetary policy regimes on the analysis.

The anticipated and unanticipated growth in the money supply were then determined. The anticipated monetary change was derived from the regression equation by inserting the actual values of the explanatory variables. The residuals from the specified models were then taken as a proxy for the unanticipated growth in money supply.

The above procedure was also followed in respect of the monetary aggregate M3. However, in this latter case, only the atheoretical model specification was applied.
Following the above procedure, regression equations were specified with the rate of change in the JSE All Share Index (DALSI) as the dependent variable and the anticipated and unanticipated changes in money supply as the independent variables. Five regression models were specified, one based on $\mathrm{M} 3$ and the other four based on M1 A. A similar procedure as described above was followed to determine the best model. This was based on significant t-values, the coefficient of determination and the BIC. Models were tested for serial correlation and heteroscedasticity.

Contrary to Bhana (1993), the share price growth equations did not contain other independent variables. By only including anticipated and unanticipated monetary growth as explanatory variables of changes in share prices the need to isolate the impact of the monetary variables, without possible interference from other variables, is eliminated. Including other independent variables in the equation may reduce the significance of the monetary variables as cross correlation between the exogenous variables will tend to reduce their individual significance.

The underlying assumption of this approach is that the monetary variables will not be significant in explaining share price movements. Should this assumption be violated by the results, it would then be necessary, as in the case of Bhana's research, to specify the model of share price movements more comprehensively. A more comprehensive model would then have the impact of reducing the significance of variables with a high cross correlation and thus making the conclusion rejecting the EMH more robust.

\section{Results}

\section{Anticipated monetary growth}

\section{Monetary aggregate $M 3$}

The results of the anticipated monetary growth equation, with the growth rate of the monetary aggregate (M3) as the dependent variable, are set out in Table 1 . The results are based on the full period from 1978 to 1993 and on the subperiod from 1984 to 1991 .

Except for the treasury bill rate (TBRATE), all the variables are specified in terms of rate of change. The $R^{2}$ of 0.40 indicates that about $40 \%$ of the change in monetary growth is anticipated by the market. The Ljung-Box test indicates that serial correlation may exist. No attempt was, however, made to correct for the possible existence of higher-order serial correlation.

The Student-t statistics indicate that all the independent variables are correctly presented in the model. Three lagged values of the dependent variable are included along with two variables reflecting a lagged change in retail sales, two variables reflecting a lagged change in the producer price index and one variable reflecting a lagged change in the treasury bill rate of interest.

A problem that arises with all the models is that it is difficult to justify the inclusion of variables on theoretical grounds only. There is no economic basis for accepting only those variables included and the lag lengths specified. Acceptance of a variable must therefore largely be based on empirical evidence making the argument that such relationships are spurious difficult to counter. An example of such an argument in the model specified in Table 1 concerns the inclusion of the 
Table 1 Anticipated monetary growth regression model

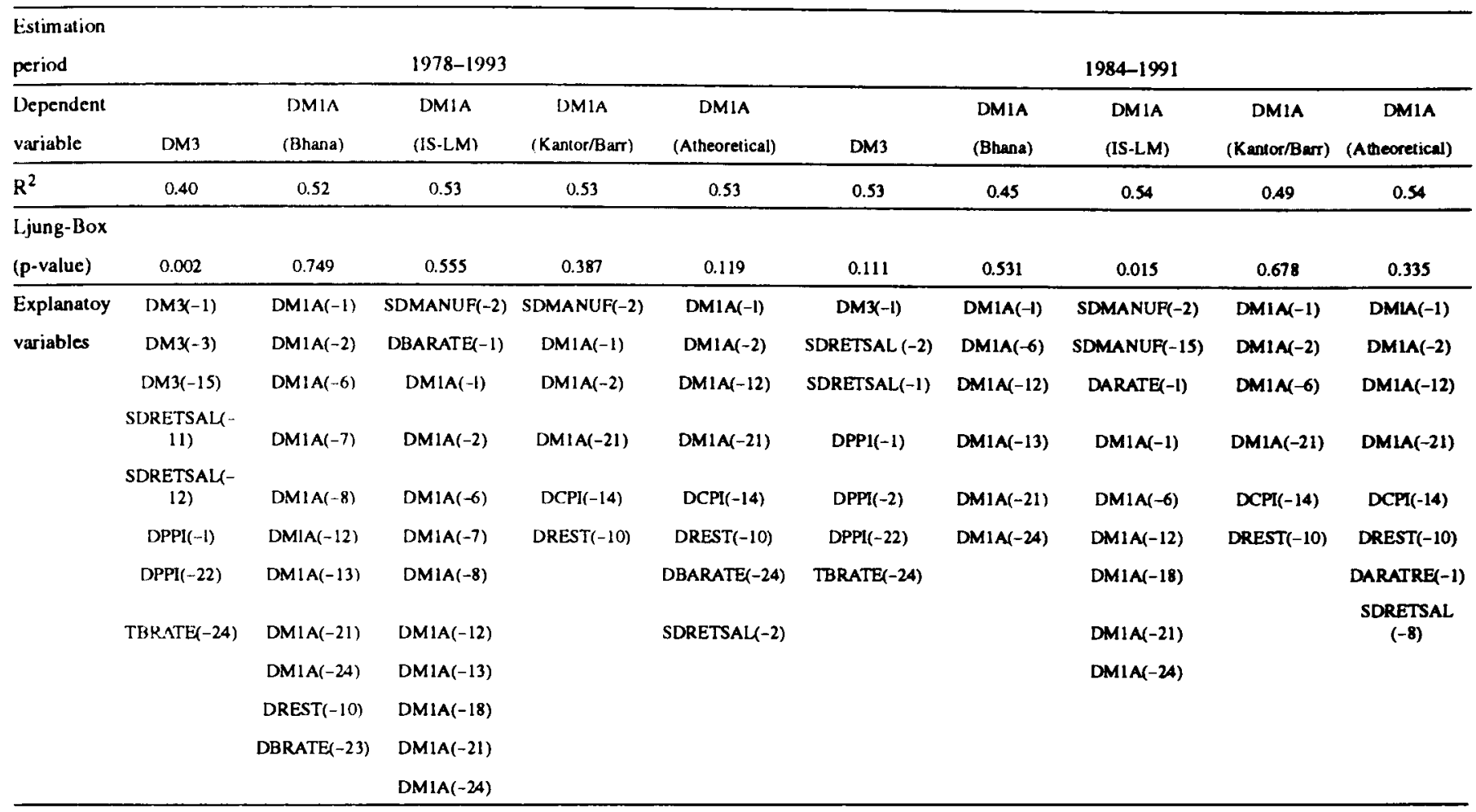

*All variables are significant at the $5 \%$ level.

** In all cases, the prefix D denotes that the variables are specified in a growth rate format. Similarly, the prefix $S$ denotes that the variables have been seasonally adjusted.

*** DM3 - growth in monetary aggregate M3; DM IA - growth in monetary aggregate M1A; SDRETSAL - seasonally adjusted growth in retail sales; DPPI growth in the Production Price Index; TBRATE - the interest rate earned on Treasury Bills; DREST - rate of change of gold and foreign exchange reserves; DBARATE - rate of change of the BA rate; BARATE - the interest rate earned on Bankers Acceptances; SDMANUF - seasonally adjusted growth rate in the Manufacturing Production Index and DCPI - rate of change in the Consumer Price Index.

TBRATE variable with a 24 period lag. However, the relationship between the interest rate and money supply cycles has been well documented and the possibility that this relationship is both empirically and theoretically sound, and not spurious, cannot be ignored. The TBRATE variable has therefore been included in the final model as empirical evidence must also play a role in deciding on which of the variables to be included.

\section{Monetary aggregate MIA}

The results of the models relating to MlA over the full period are set out in Table 1 . In all cases, the $\mathrm{R}^{2}$ s indicate that about $50 \%$ of the change in the rate of growth of the money supply is anticipated by the market. The Ljung-Box tests indicate an absence of first-order and higher-order serial correlation. The exogenous variables are included based on the Student-t statistics indicating that the variables are significant in explaining monetary growth at the $5 \%$ significance level.

The model based on Bhana's work, as well as the IS-LM model, indicates a high degree of dependence on lagged values of the endogenous variable. This dependence is reduced significantly when the model is more broadly defined to include additional variables. Both the Kantor-Barr model and the atheoretical model have a reduced number of lagged dependent variables. These latter two models further indicate a higher degree of confidence in accepting the inclusion of the explanatory variables.
The results obtained from the models relating to the money supply regime (1984-1991) are also set out in Table 1. With respect to MIA, the results are not significantly different from those obtained from the models based on the full period. With regard to $M 3$, however, the adjusted $R^{2}$ for the money supply regime model based on $\mathrm{M} 3$ implies that about $53 \%$ of the change in monetary growth was anticipated by the market. This compares with the $40 \%$ obtained from the model based on the full period. Furthermore, the Ljung-Box test for higher-order serial correlation is no longer violated when the period restriction is applied. While it is not the purpose of this article to analyse such a variance in the results, it does indicate that the identification of policy regimes has a significant impact on the test results and therefore highlights the importance of isolating the monetary policy regimes.

\section{Unanticipated monetary growth}

As previously indicated, the residuals from the models were taken as the unanticipated change in monetary growth. The importance of making this distinction is further highlighted by the fact that the explanatory powers of the anticipated monetary growth models ranges from about $40 \%$ to $54 \%$. It is implicitly assumed therefore that unanticipated changes in monetary growth explain some $46 \%$ to $60 \%$ of the change in the money supply. 
Relationship between monetary growth and share price changes

Regression models were specified for the M3 and M1A derived monetary growth variables to test for the significance of lagged changes in monetary growth on changes in share returns. A summary of the results is set out in Table 2. Only explanatory variables significant at the $5 \%$ level are shown.

In Table 2 the extent is indicated to which lagged changes in anticipated and unanticipated monetary growth are significant in explaining changes in share prices. The results relating to the money supply regime period (1984-1991), as set out in Table 3, are not substantially different from those indicated in Table 2 .

Given the EMH, it is expected that no significant relationship between lagged monetary growth and share prices will be found. However, in all cases, except for the model based on M3, lagged monetary growth variables were found to be significant when specified as the only explanatory variables of share price growth. The Student-t results in Table 2 indicate that the lagged effect varies from 3 to 12 months depending on the model assumptions. For the model based on M3, the only variable found to be significant was the contemporaneous change in anticipated monetary growth, a finding which is in violation of the EMH.

In all cases, however, the explanatory power of the models are very low suggesting that, whilst there may be a significant theoretical relationship. given transaction costs. a trading rule based on this relationship would not prove profitable. The

Table 2 Regression results of models based on anticipated and unanticipated lagged and contemporaneous changes in monetary growth (full period)

\begin{tabular}{|c|c|c|c|c|c|}
\hline Model & $\begin{array}{l}\text { Dependent } \\
\text { variable }\end{array}$ & $\begin{array}{l}\text { Significant inde- } \\
\text { pendent variables } \\
(\alpha=0.05)\end{array}$ & I-value & $\begin{array}{l}\text { Durbin- } \\
\text { Watson }\end{array}$ & $\mathbf{R}^{2}$ \\
\hline M3 & DALSI & DM3EXP & 182.6 & 1.7 & 0.00 \\
\hline \multicolumn{6}{|l|}{ Atheoretical } \\
\hline MIA & DALSI & DMIBUE[-5] & 2.6 & 1.8 & 0.06 \\
\hline \multirow[t]{2}{*}{ Bhana } & & DMIEXPB & 5.8 & & \\
\hline & & DMIEXPB [-4] & 3.9 & & \\
\hline MIA & DALSI & DM1EXPI[-9] & 5.7 & 1.7 & 0.00 \\
\hline IS/LM & & DMIEXPII-10] & 3.5 & & \\
\hline DMIA & DALSI & DMIEXPK & 2.2 & 1.8 & 0.05 \\
\hline \multirow[t]{3}{*}{ Kantor \& Barr } & & DMIEXPKI-3] & -2.1 & & \\
\hline & & DMIEXPKI-10] & 3.0 & & \\
\hline & & DMIEXPK $[-12]$ & 2.7 & & \\
\hline DMIA & DALSI & DMIEXPA & 2.5 & 1.7 & 0.03 \\
\hline \multirow[t]{3}{*}{ Atheoretical } & & DMIEXPA[-3] & -2.1 & & \\
\hline & & DMIEXPA|-9] & 2.3 & & \\
\hline & & DMIEXPA $[-10]$ & 3.4 & & \\
\hline
\end{tabular}

where: DALSI - growth rate in the All Share Index on the JSE: DMIBUE unexpected change in monetary growth derived from the Bhana model: DM3EXP - expected change in money supply derived from the M3 models; DMIEXP - expected change in money supply derived from the MIA models. The suffix meaning is as follows: $B=$ Bhana model; $I=I S-L M$ model: $K=$ Kantor \& Barr model: $\Lambda=$ Atheoretical model. coefficients of determination range from a minimum of zero (Table 2) to a maximum of $10 \%$ (Table 3 ).

\section{Conclusion}

This article empirically examines the efficiency of the JSE with regard to publicly available information about monetary policy. According to the requirements for semi-strong form efficiency, the stock market should immediately adjust to new information about monetary policy. Any delayed adjustment indicates the presence of inefficiencies as superior returns may be available to speculators or investors who are able to adjust more quickly than the market. To ensure a more rigorous test of market efficiency, monetary growth has been decomposed into anticipated and unanticipated elements.

The test results indicated in Table 2, lead to the rejection of the first null hypothesis set out in the fifth section. Evidence exists that both contemporaneous and lagged changes in anticipated monetary growth are significant in explaining share price movements. Except for the atheoretically derived model, all the models have been specified with at least one lagged value of the change in anticipated monetary growth. The atheoretical model includes only the contemporaneous change in anticipated monetary growth as an explanatory variable which is also in violation of market efficiency.

With regard to the second hypothesis, only the Bhanaderived model includes an unanticipated monetary growth variable as significant in explaining share price changes, thus rejecting the hypothesis that the market is efficient with regard to information on lagged changes in unanticipated monetary growth. However, the other models support the acceptance of this hypothesis as no evidence exists that lagged changes in unanticipated monetary growth are significant in explaining share price movements. All lagged variables, relating to unanticipated monetary growth, have been rejected by these models.

Despite the above findings, caution is required in assessing the extent to which the market is inefficient with regard to lagged changes in anticipated and unanticipated monetary growth. The test results indicate that on theoretical grounds, the market may be concluded to be inefficient. However, the low $R^{2} s$ for all the models mitigate against the power of a trading rule, based on monetary growth information, outperforming the market portfolio. The results offer little support for Bhana's (1993) contention that a trading rule based on monetary changes would have delivered superior returns, but rather supports Rozeff's (1975) conclusion that a very low percentage of the variation in share prices is explained by changes in money supply.

\section{References}

Barr, G.D.I. \& Kantor, B.S. 1990. 'The application of a vector autoregressive model to money, income and price links in the South African Economy', Journal for Studies in Economics and Econometrics, Vol. 14, No. 1: 39-49.

Barro, R.J. 1977. 'Unanticipated money growth and unemployment in the United States', American Eronomic Review, Vol. 67, No. 2: 101-115.

Bhana, N. 1993. 'The relationship between growth in money supply and share prices: a test of the efficiency of the Johannesburg Stock Exchange', Management Dynamics, Vol. 2, No. 2: 31-42. 
Table 3 Regression results of models based on anticipated and unanticipated lagged and contemporaneous chan ges in monetary growth (1984-1991)

\begin{tabular}{|c|c|c|c|c|c|}
\hline Model & $\begin{array}{l}\text { Dependent } \\
\text { variable }\end{array}$ & $\begin{array}{l}\text { Significant independ- } \\
\text { ent variables } \\
(\alpha=0.05)\end{array}$ & t-value & Durbin-Watson & $\mathbf{R}^{2}$ \\
\hline M3 & DALSI & DM3EXP & 178.3 & 1.7 & 0.02 \\
\hline \multicolumn{6}{|l|}{ Atheoretical } \\
\hline $\mathrm{M} I \mathrm{~A}$ & DALSI & DEXPB84(-4) & 3.2 & 1.76 & 0.02 \\
\hline Bhana & & DEXPB84(-9) & 4.9 & & \\
\hline$\overline{M I A}$ & DAI.SI & DEXPI84(-4) & 3.8 & 1.71 & 0.10 \\
\hline IS-LM & & DEXPI84(-9) & 4.8 & & \\
\hline$M 1 A$ & DALSI & DEXPK84(-4) & 2.5 & 1.79 & 0.03 \\
\hline Kantor/Bart & & DEXPK84(-12) & 4.6 & & \\
\hline MIA & DALSI & DEXPA84(-4) & 2.7 & 1.83 & 0.04 \\
\hline Atheoretical & & DEXPA84(-12) & 4.8 & & \\
\hline
\end{tabular}

where: DALSI - growth rate in the All Share Index: DM3EXP - the expected change in money supply; DEXP1384 - expected change in money supply derived from the Bhana model for the period 1984-1991; DIEXI'184 - expected change in money supply derived from the IS-LM model for the period 1984-1991: DEXPK84 - expected change in money supply derived from the Kantor/Bart model for the period 19841991 ; and DEXPA84 - expected change in money supply derived from the atheoretical model for the period 1984-1991.

Bonomo, V.\& Tanner, J.E. 1983. 'Expected monetary changes and relative prices: a look at evidence from the stock exchange'. Southern Economic Journal, Vol. 50: 334-345

Contogiannis, E. \& Shani, M.A. 1982. "The demand for money and inflationary expectations in South Africa, 1965-1980'. The South African Journal of Economics, Vol. 50, No. 1: 26-34.

Fama, E.F. 1990. 'Stock returns, expected returns and real activity', The Journal of Finance. Vol. 44. No. 4: 1089-1108.

Hafer, R.W. 1986. 'The response of stock prices to changes in weekly money and the discount rate'. Review of the Federal Reserve Bank of St. Louis. Vol. 68: 5-14.

Hamburger, M.J. \& Kochin. L.A. 1972. 'Money and stock prices: the channels of influence'. The Journal of Finance, Vol. 27, No. 2: 231-240.

Homa, K.E. \& Jaffee, D.M. 1971. 'The supply of money and common stock prices', The Journal of Finance, Vol. 26, No. 5: 10451066.

Jensen, M. 1978. 'Some anomalous evidence regarding market efficiency', Journal of Financial Economics, Vol. 6: 95-101.

Keran. M.W. 1971. 'Expectations, money and the stock market'. Review Federal Reserve Bank of St. Louis. January, 16-31.

Mishkin. F.S. 1982. 'Does anticipated monetary policy matter? An econometric investigation', Journal of Political Economy. Vol. 90: $22-51$.
Pearce, D.K. \& Roley, V.V. 1983. 'The reaction of stock prices to unanticipated changes in money: a note', The Journal of Finance, Vol. 38, No. 4: 1323-1333.

Rozeff, M.S. 1974. 'Money and stock prices', Journal of Financial Economics, Vol. 1: 245-302.

Rozeff, M.S. 1975. 'The money supply and the stock market', Financial Analysts Journal, September-October, 18-25.

Smit, E vd M. \& Philip, L.W. 1992. 'Share returns, inflationary expectations and monetary policy: the South African experience', Journal for Studies in Economics and Econometrics, Vol. 16, No. 3: 17-34.

Sorensen, E.H. \& Arnott, R.D. 1988. 'The risk premium and stock market performance', Journal of Portfolio Management, Vol. 14: 50-55.

Sprinkel, B.W. 1964. Money and stock prices. Homewood, Illinois: Richard D. Irwin.

Tavlas, G.S. 1989. 'The demand for money in South Africa: a test of the buffer stock model', The South African Journal of Economics, Vo1. 57, No. 1: 1-13.

Whittaker. J. \& Theunissen, A.J. 1987. 'Why does the Reserve Bank set the interest rate?'. The South African Journal of Economics, Vol. 55, No. 1: 16-32. 